\title{
Üç Aylık Bebekte Tüberküloz Lenfadenit
}

\author{
Tuberculosis Lymphadenitis in a Three Month Old Baby
}

\author{
Bahri Elmas ${ }^{1}$, Onur Bircan ${ }^{1}$, Gizem Ay ${ }^{1}$, Öner Özdemir², Mustafa Büyükavcı ${ }^{3}$ \\ ${ }^{1}$ Sakarya Üniversitesi Tip Fakültesi Pediatri ABD, Sakarya, Türkiye \\ ${ }^{2}$ Sakarya Üniversitesi Tip Fakültesi Pediatri ABD, Pediatrik Allerji-Immünoloji BD, Sakarya, Türkiye \\ ${ }^{3}$ Sakarya Üniversitesi Tip Fakültesi Pediatri ABD, Pediatrik Hematoloji-Onkoloji BD, Sakarya, Türkiye \\ Yazış̧a Adresi / Correspondence: \\ Dr. Onur Bircan \\ Sakarya Üniversitesi Eğitim ve Araştırma Hastanesi Pediatri Kliniği, Adapazarı/Sakarya \\ T: +90505 2465112 E-mail: dronurbircan@gmail.com \\ Orcid \\ Bahri Elmas : http://orcid.org/0000-0001-9034-6109 \\ Onur Bircan : https://orcid.org/0000-0002-0920-7652 \\ Gizem Ay : https://orcid.org/0000-0003-4573-0413 \\ Öner Özdemir : https://orcid.org/0000-0002-5338-9561 \\ Mustafa Büyükavcı : https://orcid.org/0000-0002-9054-3134 \\ Geliş Tarihi / Received : 27-07-2019 Kabul Tarihi / Accepted : 05-08-2019 Yayın Tarihi / Online Published: 29-08-2019
}

Elmas B., Bircan O., Ay G., Özdemir Ö., Büyükavcı M., Üç Aylık Bebekte Tüberküloz Lenfadenit

J Biotechnol and Strategic Health Res. 2019;3(2):148-152 DOI: 10.34084/bshr.597630

\begin{tabular}{ll}
\multicolumn{1}{l|}{ Özet } & \\
\hline & Tüberküloz lenfadenit ülkemiz gibi tüberkülozun sık görüldüğü ülkelerde çocukluk çağında akciğer dışı tüberkülozun en sık rastlanan formu olarak karşımıza çıkmaktadır. \\
Çocuklarda sıklı̆ının \%35-67 arasında değiştiği ve en sık servikal lenf nodlarında tutulum olduğu bildirilmektedir. 3 aylık kız hasta ateş, solunum sıkıntısı ve boyunda \\
şişlik nedeni ile çocuk servisine yatırıldı. Akut lenfadenit ön tanısılla ampirik antibiyotik tedavisi başlandı. Ampirik antibiyotik tedavisine yanıt vermeyen hastaya yapılan \\
TDT endürasyon çapı 18 mm ölçüldü. Aynı dönemde anne de tüberküloz tanısı aldı. Açlık mide suyunda ARB pozitif değerlendirildi. Tüberküloz PCR ile mycobacterium \\
tuberclosis saptandı. Anti tüberküloz tedavi başlanan hasta da tedavi sonrası tam remisyon sağlanmıştır. Servikal lenfadenopati ayırıcı tanısında özellikle erken süt \\
çocukluğu döneminde tüberküloz öncelikli olarak düşünülmeyebilir. Sik görülen bir form olması nedeni ile lenfadenopatili hastalarda her yaşta tüberküloz düşünülmelidir. \\
Anahtar & Lenfadenit, Süt çocuğu, Tüberküloz \\
Kelimeler &
\end{tabular}

Abstract

Tuberculosis lymphadenitis is the most common form of extrapulmonary tuberculosis in childhood in countries where tuberculosis is common. It has been reported that the incidence varies between 35-67\% in children and the most common involvement is cervical lymph nodes. A 3-month-old girl was admitted to the pediatric clinic because of fever, respiratory distress and swelling on the neck. Empirical antibiotic treatment was initiated with a preliminary diagnosis of acute lymphadenitis. The TBT induration diameter of the patient, who did not respond to empirical antibiotic therapy, was measured $18 \mathrm{~mm}$. At the same time, the mother was diagnosed with tuberculosis. ARB positivity was found in morning gastric aspirate before meal. Mycobacterium tuberclosis was detected by tuberculosis PCR. Anti-tuberculosis treatment was initiated and complete remission was achieved after the treatment. Tuberculosis may not be considered primarily in the differential diagnosis of cervical lymphadenopathy especially in early infancy. Tuberculosis should be considered at all ages in patients with lymphadenopathy because of its prevalence.

Keywords Infant, Lymphadenitis, Tuberculosis 


\section{GIIRIŞ}

Tüberküloz tüm dünyada ve ülkemizde yüksek mortalite ve morbiditeye sahip önlenebilir ve tedavi edilebilir bir halk sağlığı problemidir' ${ }^{1}$. Türkiye'de Verem Savaşı 2018 raporunda 2016 yılında Türkiye’nin tüberküloz insidansı yüzbinde 15.3, 15 yaş altı çocuk tüberküloz hastalarının oranı ise tüm hastaların içinde \%5.3 olarak bildirilmekte$\operatorname{dir}^{2}$. Süt çocukluğu döneminde Mikobakterium tuberkülozis ile karşılaşma sonrası uygun tedavi verilmeyenlerde hastalık gelişme ihtimali \%50 ve 6 ay altındaki çocuklarda mortalite \%50'nin üzerindedir ${ }^{3}$. Mycobacrium tuberculosis primer olarak akciğerlerde enfeksiyona sebep olsa da, çocuklarda immün sistemin henüz immatür olması nedeniyle lenfohematojen yayılımla akciğer dışı tüberküloz sıklığında artış görülmektedir ${ }^{4}$. Tüberküloz lenfadenit ülkemiz gibi tüberkülozun sık görüldüğü ülkelerde çocukluk çağında akciğer dışı tüberkülozun en sık rastlanan formudur ${ }^{5}$. Akut servikal lenfadenit nedeniyle başvuran ve tüberküloz lenfadenit tanısı alan 3 aylık kız hasta, erken süt çocukluğu döneminde servikal lenfadenit nedenleri arasında tüberkülozun da düşünülmesi gerektiğini vurgulamak amaciyla sunulmuştur.

\section{OLGU SUNUMU}

Üç aylık kız hasta ateş, solunum sıkıntısı ve boyunda şişlik nedeni ile çocuk servisine yatırıldı. Başvuru öncesi yedi gün bronşiolit tanısıyla izlendiği öğrenildi. Fizik muayenesinde her iki servikal bölgede sert, konglomere ve çok sayıda lenfadenopati mevcut idi (Resim 1).

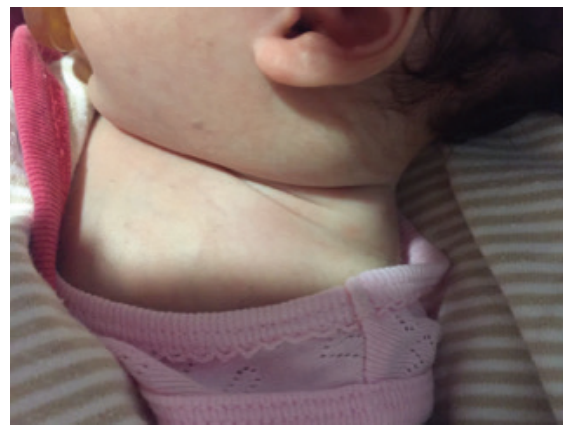

Resim 1: Sol servikal bölgede konglomere lenfadenopati görünümü
Akciğerlerde bilateral sibilan ronküsler alınıyordu. Lökosit sayıs $25100 / \mathrm{mm} 3$, eritrosit sedimentasyon hızı 33mm/ sa, CRP: $268 \mathrm{mg} / \mathrm{L}$, anti-CMV IgM 12.7(pozitif), anti-CMV IgG: 54.6(pozitif) bulundu. Annede anti CMV IgG: 197.6 (pozitif), CMV PCR negatif bulundu. Boyun ultrasonografisinde submandibuler ve servikal yerleşimli büyüğü 16mm ölçülen multipl hipoekojen lenfanopati ve çevre yumuşak dokularda ödem ve enflamasyon bulguları saptandı. Nonspesifik tedavi başlanan hastanın lenfadenopatilerinde belirgin düzelme izlenmedi ve PPD 18 mm ölçüldü. Annesine akciğer tüberkülozu tanısı konulan hastadan istenen toraks CT incelemesinde her iki akciğer apekslerde belirgin olmak üzere yer yer buzlu cam dansitesinde alanlar, konsolidasyonlar ve interlobüler septal kalınlaşmalar saptandı (Resim 2).
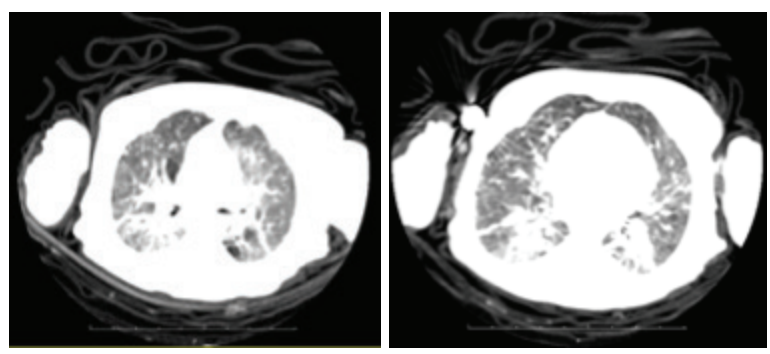

Resim 2: Toraks CT incelemesinde yer yer buzlu cam dansitesinde alanlar, konsolidasyonlar ve interlobüler septal kalınlaşmalar.

Ayrıca mediasten, aksillar ve servikal bölgede lenfadenopatiler saptandı (Resim 3). BOS tüberküloz PCR ve tüberküloz kültürü negatif, BOS şekeri ve proteini normal bulundu. Açlık mide suyunda ARB bir örnekte pozitif bulundu ve tüberküloz PCR incelemesinde mycobacterium tuberculosis saptandi. Hastaya izoniyazid, rifampisin, pirazinamid ve etambutolden oluşan dörtlü anti-tüberküloz tedavi başlandı. Takibinin ikinci ayında herhangi bir semptomu bulunmayan hastanın tedavisi izoniyazid ve rifampisin olarak altı aya tamamlandı. Kontrol toraks CT incelemesi normal bulundu. 


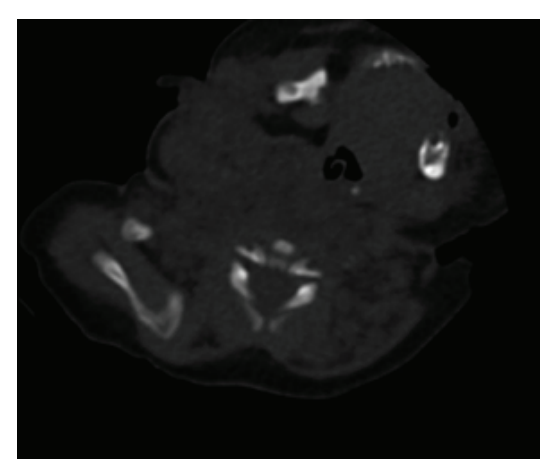

Resim 3: Servikal CT incelemesinde sol servikal bölgede konglomere lenfadenopatiler

\section{TARTIŞMA}

Tüberküloz lenfadenit çocukluk çağında en sık görülen akciğer dışı tüberküloz formudur6. Türkiye’de Verem Savaşı 2018 Raporuna göre 2016 yılında 15 yaş altı tüberküloz hastası 630 çocuğun 242 (\%38.4)'sinde akciğer dışı tüberküloz tutulumu varken 54'ünde (\%8.5) hem akciğer hem de akciğer dışı tutulum bulunduğu bildirilmiştir². Özellikle bir yaş altı çocuklarda milier tüberküloz riski ve mortalitesi yüksektir7. Bu yaş grubunda lenfohematojen yayılımın daha fazla olması nedeni ile akciğer dışı enfeksiyon oranı daha yüksektir ${ }^{4}$. Kaba ve ark. tarafından yapılan çalışmada 4 yaş altı tüberkülozlu çocukların \%37.1'inde ekstrapulmoner tüberküloz saptandığı rapor edilmiştir.

Tüberkülozlu çocuk hastalarda ateş, öksürük, kilo kaybı gibi sistemik semptomların yanında lenfadenopati, gastrointestinal tutulum, kemik ve eklem enfeksiyonu, periton ve plevral tutulum gibi değişik organ ve sistemlerin tutulumu görülebilmektedir. Tüberküloz lenfadenit çocukluk çağında akciğer dışı tutulumun en sık nedenlerinden birisi olup yavaş büyüyen, ağrısız ve sert lenfadenopati en önemli bulgudur'. Sepulweda ve ark. tarafından yapılan çalışmada 0.8-17 yaş arasındaki 32 tüberkülozlu çocuk hastada sistemik semptomlardan ateş $\% 40.6$, öksürük \%18.8, kilo kaybı \%15.6 ve iştahsızlık \%12.5 olarak bulunurken akciğer dışı bulgulardan lenfadenopati \%40.6, meningeal tutulum \%21.9 ve göz tutulumunun \%18.8 olarak saptandığ 1 bildirilmiştir
- Devrim ve ark.'ları tarafından çocuklarda akciğer tüberkülozu ve akciğer dışı tüberküloz bulgularının karşılaştırıldığı çalışmada; akciğer dışı tüberküloz hastalarında ateş, kilo kaybı, halsizlik gibi semptomların daha az oranda görüldüğü bildirilmiştiir ${ }^{10}$. Aygün ve ark. tarafından yapılan çalışmada yaşları 3-204 ay aralığında olan ve akciğer dışı tüberküloz tanısı alan 90 hastanın \%32.2'si tüberküloz lenfadenit olarak bildirilmiştir ${ }^{11}$. Bozdemir ve ark. tarafindan 2005-2010 ylları arasında tüberküloz lenfadenit tanısı alan 19 olgu arasında yapılan çalışmada en sık görülen lenf nodu tutulumunun servikal bölge (\%47.4) olduğu bildirilmiştiri ${ }^{12}$. Bizim vakamızda da literatürde en sık akciğer dışı tutulum bölgesi olarak bildirilen servikal lenf nodlarında tutulum gözlenmiştir. Vakamızda başvuru anında servikal lenfadenit ile birlikte ateş, solunum sıkıntısı ve akciğerlerde ronküsler saptanmıştır. Bir yaş altında olması nedeni ile milier tüberküloz açısından yapılan toraks CT'de bulguya rastlanmamıştır. Ayrıca santral sinir sistemi tulumu açısından yapılan BOS incelemesinde PCR ile etken saptanmamıştır.

Unterweger ve arkadaşlarının 2010-2016 yılları arasında Viyana'da aktif tüberkülozu olan 127 hasta çocuk içeren grup ile yaptığı çalışmada hastalarının \%35'inin ebeveynlerinden birinin aktif tüberküloz hastalığı olduğu ve bunun vakanın başlangıç noktası olduğu işaret edilmiştitir ${ }^{13}$. Bizim vakamızda da kaynağın aktif tüberküloz tanısı alan anne olduğu saptanmış ve anneye tedavi başlanmıştır.

Tanıda altın standart olarak kabul edilen kültürün, büyük çocuklara göre süt çocuklarında özellikle mide aspirasyon sıvısından yapıldığında daha anlamlı olduğu bildirilmektedir ${ }^{14}$. Beş yaş altı çocuklarda quantiferon testinin yeterli güvenilirlikte olmaması nedeni ile tüberkülin deri testi (TDT) pozitifliğinin daha duyarlı olduğu bildirilmektedir15. Bozdemir ve ark tarafından 12 ay- 16 yaş aralığındaki tüberküloz lenfadenit tanısı alan 19 olguda yapılan çalışmada TDT pozitiflik oranı \%78.9 olarak saptanmıștır ${ }^{12}$. Aygün ve ark. tarafından yaşları 3-204 ay aralı̆̆ında olan ve akciğer dışı tüberküloz tanısı alan 90 hasta ile yapılan çalış- 
mada ise TDT pozitiflik oranı $\% 48.9$ olarak saptanmıştır ${ }^{11}$. Tüberküloz lenfadenit düşünülen hastalarda tanısal amaçlı ince iğne aspirasyon ve ya eksizyonel biyopsinin de yapılabileceği bildirilmektedir ${ }^{16}$. Annede aktif tüberküloz hastalığı saptanan vakamızda da başvuru anında yapılan TDT pozitif olarak saptanmıştır. Beş yaş altında olması nedeni ile quantiferon testi yapılmayan vakamızda açlık mide suyunda ARB pozitif bulunmuş ve PCR ile mikobakterium tüberkülozis pozitif olarak saptanmıştır. TDT pozitifliği ve etkenin açlık mide suyunda saptanması nedeni ile lenf nodlarından biyopsi yapılması düşünülmemiştir.

Amerika Enfeksiyon Hastalıkları Derneği Klinik Uygulama Kılavuzunda, nadir durumlar dışında tüberküloz lenfadenit vakalarında tedavi amaçlı lenf nodu eksizyonu önerilmemektedir. Tedavide antitüberküloz ilaçlar kullanılmaktadır ${ }^{17}$. Bizim vakamızda da iki aylık dörtlü anti-tüberküloz tedavi sonrasında iki ilaçla devam edilen toplam altı aylık tedavi ile tam iyileşme sağlanmıştır.

Sonuç olarak; özellikle erken süt çocukluğu döneminde subakut veya kronik lenfadenopati ile başvuran ve antibiyotik tedavisine yanıt vermeyen olgularda bu dönemde öncelikli olarak düşünülmeyebilen tüberküloz lenfadenitin unutulmaması gereklidir. 
Journal of BSHR 2019;3(2):148-152

\section{Kaynaklar}

1. World Health Organization. Global tuberculosis report 2017. Geneva: World Health Organization; 2017. (cited 2019 June 27). Available from: URL: https://www. who.int/tb/publications/global_report/gtbr2017_main_text.pdf.

2. Türkiyede Verem Savaş Raporu 2018. Available from: https://hsgm.saglik.gov.tr/depo/ birimler/tuberkuloz_db/dosya/raporlar/Tu_rkiye_de_Verem_Savas_2018_Raporu_kapakl_pdf.

3. Vanden Driessche $K$, Persson A, Marais BJ, et al. Immune vulnerability of infants to tuberculosis. Clin Dev Immunol. 2013; 2013: 781320. doi: 10.1155/2013/781320. .

4. Santiago-García B, Blázquez-Gamero D, Baquero-Artigao F, et al; EREMITA Study Group. PediatricExtrapulmonary Tuberculosis: Clinical Spectrum, Risk Factors and Diagnostic Challenges in a Low Prevalence Region. Pediatr Infect Dis J. 2016; 35(11): 1175-1181. .

5. Sepulveda EVF, Yunda LFI, Herrera KCM, et al. Extrapulmonary tuberculosis in colombian children: Epidemiological and clinical data in a reference hospital. Int J Mycobacteriol. 2017; 6(2): 132-133.

6. Marais BJ, Wright CA, Schaaf HS, et al. Tuberculous lymphadenitis as a cause of persistent cervical lymphadenopathy in children from a tuberculosis endemic area. Pediatr Infect Dis J. 2006; 25(2): 142-146.

7. Gündeșlioğlu ÖÖ, Kocabaș E. Extrapulmonary Tuberculosis in Childhood. Turkiye Klinikleri J Pediatr Sci 2016; 12(3): 32-38.

8. Kaba Ö, Kara M, Odactlar CA, et al. Evaluation of cases of pediatric extrapulmonary tuberculosis: a single center experience. Turk Pediatri Ars 2019; 54(2): 86-92.

9. Geldmacher H, Taube C, Kroeger C, et al. Assessment of lymph node tuberculosis in northern Germany: a clinical review. Chest 2002. 121(4): 1177-1182.
10. Devrim I, Aktürk H, Bayram N, et al. Differences between pediatric extra-pulmonary and pulmonary tuberculosis: a warning sign for the future. Mediterr J Hematol Infect Dis. 2014; 6(1): e2014058. doi: 10.4084/MJHID.2014.058.

11. Aygün D, Akçakaya $N$, Çokuğraş $H$, et al. Clinical manifestations and diagnosis of extrapulmonary tuberculosis in children. J Pediatr Inf 2019; 13(2): e74- e79. doi: 10.5578/ ced.201922.

12. Bozdemir ȘE, Nazloğlu HÖ, Hacımustafaoğlu M, et al. Çocuklarda Tüberküloz Lenfadenit. J Pediatr Inf 2012; 6(1): 6-11. doi:10.5152/ced.2012.02.

13. Unterweger M, Götzinger F, Bogyi M, et al. Childhood tuberculosis in Vienna between 2010 and 2016. Wien Klin Wochenschr. 2019. doi: 10.1007/s00508-019-1510-9.

14. Vallejo JG, Ong LT, Starke JR. Clinical features, diagnosis, and treatment of tuberculosis in infants. Pediatrics. 1994; 94(1): 1-7.

15. Nakaoka H, Lawson L. Risk for tuberculosis among children. Emerging Infectious Diseases. 2006; 12(9): 1383-1388. doi: 10.3201/eid1209.051606.

16. Ellison E, Lapuerta P, Martin SE. Fine needle aspiration diagnosis of mycobacterial lymphadenitis. Sensitivity and predictive value in the United States. Acta Cytol 1999; 43(2): 153-157.

17. Nahid P, Dorman SE, Alipanah N, et al. Official American Thoracic Society/Centers for Disease Control and Prevention/Infectious Diseases Society of America Clinical Practice Guidelines: Treatment of Drug-Susceptible Tuberculosis. Clin Infect Dis. 2016; 63. ;63:e147-e195. 